\title{
Em busca do tempo passado: considerações sobre a memória em Memórias de um sobrevivente, de Luiz Alberto Mendes
}

\author{
Adauto Locatelli Taufer*
}

\begin{abstract}
Resumo: O presente artigo parte de pressupostos Abstract: The present article is based on theoretical teóricos desenvolvidos ao longo de minha dissertação presuppositions developed in my Master's thesis titled de mestrado, intitulada "Do factual ao ficcional: "From the factual to the fictional: memory, History, memória, história, ficção e autobiografia nas Memórias fiction and autobiography in Memórias de um de um sobrevivente, de Luiz Alberto Mendes". Devido sobrevivente, by Luiz Alberto Mendes". Due to the fact ao fato da obra estudada portar o vocábulo "memórias" that the studied work has the word "memories" in its em seu título, julgo ser pertinente uma investigação title, I consider an investigation concerning such aspect acerca de tal aspecto. Procuro, desse modo, identificar would be relevant. Therefore, I try to identify the way a maneira como o texto desse escritor se insere dentro Mendes' text falls within that context, how it builds desse contexto, como ele constrói o narrador que narra the narrator who tells the memories, how the voluntary as memórias, como as memórias voluntária e and involuntary memories, postulated by Proust, find involuntária, postuladas por Proust, encontram resonance in his work and, besides, the way the studied ressonância dentro de sua obra e, além disso, a maneira author retains the memory.

como o autor referido retém a memória.
\end{abstract}

Palavras-chave: Luiz Alberto Mendes; memória; Keywords: Luiz Alberto Mendes; memory; jail. cárcere.

\begin{abstract}
A memória extrai de uma história espiritual mais ou menos remota um sem-número de motivos e imagens, mas, ao fazê-lo, são os conflitos do aqui-e-agora que a levam a dar uma boa forma ao legado aberto e polivalente do culto e da cultura. [...] O passado ajuda a compor as aparências do presente, mas é o presente que escolhe na arca as roupas velhas ou novas. (BOSI, Dialética da colonização, 1992, p.35)
\end{abstract}

\section{Algumas observações sobre a memória}

$\mathrm{O}$ estudo dos aspectos relacionados à memória é um ato que requer muita atenção e disciplina, uma vez que tal feito implica imergir numa ampla esfera de indagações, a qual nos conduz para muito além das definições que a restringem a um mero arquivamento das

\footnotetext{
* Prof. Ms. Adauto Locatelli Taufer é mestre em Literatura Brasileira pela Universidade Federal do Rio Grande do Sul - UFRGS, Programa de Pós-Graduação em Letras - PPGLET-UFRGS. Atualmente, é doutorando na mesma área de concentração na instituição referida. adautotaufer@gmail.com.
} 
informações pretéritas. Ao penetrarmos nesse vastíssimo campo, devemos considerar, sobretudo, que a rememoração das impressões passadas, trazidas para um tempo posterior através da função psíquica, porta o traço indestrutível da experiência. Até um determinado ponto, podemos considerar essa prática como característica da experiência singular, na medida em que está contida nas lembranças dos acontecimentos que compõem a vida interior do ser humano. Atentamos, entretanto, para o fato de que a experiência individual se desenvolve no convívio com um dado grupo social e que, muitas vezes, para construir a si próprio o indivíduo precisa resgatá-lo. Com isso, ele penetra no campo da memória coletiva, ainda que permaneça, devido ao seu próprio ponto de vista, no âmbito da consciência pessoal. É importante observarmos, ainda, que o vocábulo "experiência" abarca um conjunto de possibilidades, dentre as quais está o tempo.

“Ao medir o tempo, o espaço é quem responde" (BERGSON, 1989a, p.233). Partindo da perspectiva de Henri Bergson, o tempo pode ser lido enquanto espaço em cuja dimensão podem ser alinhavados o passado, o presente e o futuro, mas torna-se impossível apreendê-lo em bloco, como um todo. Se o admitirmos dessa forma, estaremos renegando a idéia de que possa surgir uma ação totalmente nova entre os momentos sucessivos do tempo, em nível interior.

Não é nenhuma novidade que o questionamento sobre as dimensões temporais não constitui exclusivamente uma preocupação da modernidade. Santo Agostinho nas suas Confissões já observava que talvez fosse mais certo se dizer: "há três tempos: o presente do passado, o presente do presente e o presente do futuro, porque essas três espécies de tempos existem em nosso espírito" (1991, p.227).

Visto na perspectiva desse filósofo, o tempo parece deter-se no presente muito mais do que em qualquer outra dimensão temporal. Quando relacionado à sua finitude, o passado remete a uma determinada impotência, uma vez que as razões finitas sugerem a possibilidade do esquecimento.

Não podemos nos esquecer, também, como sublinha LE GOFF de que "a distinção entre o passado e o presente é um elemento essencial da concepção do tempo" (2003, p.207). Ao considerarmos que o passado é prescindível, por exclusão, determinaremos o presente como o que interessa, ou seja, como a única forma de conduzir à ação. E, ao fazermos isso, estaremos admitindo a divisibilidade do tempo e, conseqüientemente, a exclusão de certos eventos que compõem a experiência vivida. Nossas lembranças, para BERGSON, entretanto,

enquanto passadas, são ao contrário pesos mortos que arrastamos conosco e dos quais gostaríamos de nos fingir desvencilhados. O mesmo instinto, em virtude do qual abrimos 
indefinidamente diante de nós o espaço, faz com que fechemos atrás de nós o tempo à medida que ele passa. (BERGSON, 1990, p. 119)

A indivisibilidade do tempo parece-nos ser um dos fatores que conduzem à consciência. E “toda consciência é memória” (BERGSON, 1989b, p.191). Memória, em geral, é o acúmulo e a retenção do passado no presente. Se toda consciência é memória, é também antecipação do futuro, uma vez que nosso espírito ocupa-se do que ele é, mas, sobretudo, do que ele será a partir do que ele foi. Diante disso, podemos afirmar que a consciência acumula uma dupla função: de reter o que já ocorreu e de antecipar o que ainda não ocorreu. $\mathrm{O}$ hiato entre o passado e o futuro é um instante tênue e genuinamente teórico. Um instante impossível de ser captado, pois, quando o capturamos, ele já se torna passado. Sob esse prisma, a consciência é, portanto, o encontro do passado com o futuro e é também a razão pela qual o tempo interior não se divide.

Se "não há consciência sem memória" (BERGSON, 1989c, p.114), parece-nos importante que pensemos a vida enquanto um acréscimo consecutivo de experiências que nos remetam sempre ao passado. Fatalmente, essa movimentação sucessiva implica a problematização do esquecimento, uma vez que este é o pressuposto para que exerçamos o ato de (re)lembrar. BERGSON corrobora nossa reflexão ao afirmar que "não há continuação de um estado sem adição, ao sentimento presente, da lembrança de movimentos passados" (id., p.145).

As experiências vividas e o tempo penetram-se reciprocamente e aglomeram-se constituindo uns dos principais alicerces da vivência humana. Essa relação de dependência entre o tempo e as experiências vividas é comprovada pela memória que do passado se estende ao presente num contínuo processo de "duração interior" (ibidem). Acerca desse aspecto da memória, BERGSON nos diz que

\begin{abstract}
é se se quiser, o desenrolar de um novelo, pois não há ser vivo que não se sinta chegar pouco a pouco ao fim da sua meada; e viver consiste em envelhecer. Mas é, da mesma maneira, um enrolar-se contínuo, como o de um fio numa bola, pois nosso passado nos segue, cresce sem cessar a cada presente que incorpora em seu caminho; e consciência significa memória. (BERGSON, 1989c, p.136)
\end{abstract}

Se entendermos esse processo de duração interior, de acordo com o que nos revela Bergson, como sendo um exercício de memória estendido até o presente, podemos pressupor que o mesmo processo também possua a capacidade de organizar os vestígios dessa memória a cada releitura que dela se fizer. Tal organização das lembranças nos permite afirmar que o ato de narrar, além de comportar uma função objetiva, caracteriza-se por abarcar uma "função 
social" (LE GOFF, 2003, p.421). ${ }^{1}$ Entendemos que tal função ocorreria em razão de a comunicação ser essencialmente a transmissão de um acontecimento a outrem.

Como destaca Maurice Blanchot, "as lembranças são necessárias para serem esquecidas" (1987, p.83). Para que, durante esse período de esquecimento, no silêncio de uma profunda metamorfose, uma palavra ou uma lembrança nasçam. Nesse sentido o que está em jogo nas $M s$ a produção de uma literatura que ilustra uma verdade previamente conhecida. Segundo Costa Lima (2000) no comentário crítico elaborado sobre Catástrofe $e$ representação, organizado por Arthur Nestrovski e Márcio Seligmann-Silva, a retomada do testemunho no contexto contemporâneo altera substancialmente o sentido dos termos. No caso de Luiz Alberto Mendes, essa recapitulação dos eventos silenciados pela repressão vivida no cárcere constitui-se numa "literatura de cicatrizes", como denominou Márcio Seligmann-Silva (apud LIMA, 2000). A prisão do autor das $M s$ não foi apenas restrita ao sistema carcerário. Estamos querendo dizer com isso que, durante um bom tempo, suas idéias também foram aprisionadas. Quando ele compõe suas memórias, portanto, ele procura se desvencilhar dos fantasmas que o assombraram e que ainda o acompanham no ato da rememoração.

É fato, contudo, que muitos eventos permanecem na esfera do silêncio, restritos ao campo daquilo que não pode ser dito nem tocado, e que Luiz Alberto Mendes, portanto, se sente no direito de não revelar ao leitor. Sua escritura, nesse sentido, em vez de revelar grandes segredos, tão caros ao gênero memorialístico-autobiográfico, se configura apenas como a denúncia e a crítica aos padrões sociais vigentes, à discriminação dos marginais/marginalizados; enfim, como uma literatura de resistência.

Ao ponderarmos sobre a posição do sujeito na sua relação com a experiência, imediatamente refletimos acerca de quem atribui a si próprio o direito de transmiti-la. Em função disso, cremos que a discussão inicial remeta à mitologia grega, em que encontramos Mnemosyne, "mulher de idade quase madura" (COMMELIN, 1978, p.261) que segura o queixo em atitude meditativa. Mnemosyne, com efeito, era, para os gregos antigos, a mãe das musas: através de sua arte, o indivíduo criador tinha acesso à própria memória, ou, melhor, às camadas mais profundas da memória coletiva. Com os gregos, assim, já podemos ver a natureza meditativa da atividade do artista: o artista é aquele que tem a função de estabelecer uma ponte, ou seja, um elo entre os homens do passado, os do presente e os do futuro. Essa

\footnotetext{
${ }^{1}$ Para esse autor, quando interpreta o pensamento de Pierre Janet, o ato mnemônico de fundamental importância está no comportamento narrativo e sublinha a função social deste quando efetivado através da comunicação.
} 
construção alegórica da deusa da memória permite-nos observar um aspecto relevante no ato de representar essa entidade mitológica. Tal característica está relacionada às marcas temporais, uma vez que a escultura da deusa destaca, por meio das marcas exteriores, a idade avançada. Graças a essa caracterização física, a passagem do tempo se torna exteriormente visível. A marca temporal, com efeito, remete à lembrança de um passado caracterizado pelo acúmulo das experiências vividas. Estas, associadas à idade avançada, concedem a Mnemosyne o substrato tão caro à meditação, possibilitando o "exercício do pensamento sobre si mesmo" (FOUCAULT, 1992a, p.133), cujas sensações já experimentadas - além de serem reativadas - podem organizar-se interiormente.

Então, a possibilidade de evocação - enquanto exercício do pensamento - é assinalada pelo ato de meditação. Atitude, aliás, praticada pelo indivíduo no presente, mas que lhe possibilita trazer à tona lembranças vividas ou presenciadas em determinado tempo e/ou lugar, revivendo, desse modo, sensações e imagens pretéritas. Com base nisso, compreendemos que o exercício da lembrança torna-se possível graças à supressão de acontecimentos antigos, arquivados na memória. Enquanto "representação de um objeto ausente" (BERGSON, 1990, p.56), tais lembranças sobrevivem misturando-se às imagens obtidas pela percepção atual do indivíduo. É, assim, o presente se fundindo ao passado para (res)significar este e atribuir sentido àquele. Sendo assim, o presente atualiza o passado a partir do apelo lançado às zonas mais íntimas da memória. O passado contido nessas camadas mais profundas permanece no inconsciente, mas é passível de ser deslocado por estar submetido a um estado de latência.

$\mathrm{Na}$ obra de Luiz Alberto Mendes, o tempo e as experiências interpenetram-se e acumulam-se formando um consistente arcabouço para a sua existência. A tentativa de estabelecer as possíveis relações entre o vivido e o narrado nos permite afirmar que esse escritor, numa idade avançada, arroga para si o ofício de arquivista, retirando dos acontecimentos anteriores o conteúdo para a feitura do texto. É o que subjaz na observação de Antonio Candido, quando diz: "Para Graciliano Ramos a experiência é condição da escrita [...]" (1992, p.58). O mesmo se aplica para Luiz Alberto Mendes, ou seja, para esse autor, a experiência é condição sine qua non para a escrita.

Sendo o relato de um momento específico da vida do autor-narrador-personagem, as Ms tomam esse momento como o fio da meada para o balanço da vida inteira. As situações outrora vividas suscitam lembranças de outros momentos da vida, marcados, sobretudo, pela opressão. Nas $M s$, a memória se curva ao desejo do intelecto que seleciona as lembranças e reflete sobre elas. É, portanto, uma escrita de si mesmo, originada do exercício do pensamento 
após longo distanciamento dos episódios vividos desde a infância, que se estende como um forte convite, ao longo da narrativa, à reflexão sobre a organização carcerária e suas formas de repressão, explicitamente abordadas por esse escritor que conhece profundamente o tal sistema e que sobreviveu a ele.

O personagem Luiz Alberto Mendes, o "Luizinho", ao rememorar seu passado, problematiza sua identidade enquanto relê e revive as situações pretéritas. Essa recordação, em vez de trazer a solução para o problema, acentua-o, demonstrando que o autor, convertido em leitor de si próprio, recusa qualquer solução definitiva. Projetando-se como personagem, o autor (re)cria um duplo de si mesmo, desdobra-se em (anti)herói. Tal desdobramento parece ser um ato de diferenciação, como tentativa de recompor a identidade, embora ela pareça inevitavelmente perdida. $\mathrm{O}$ ato de se diferenciar é uma condição para a sua busca, é o caminho para a autoconsciência, pois é a partir dela que a identidade se torna um projeto. Segundo Hegel (1973, p.?) "É o outro que torna o eu possível”. O aspecto da diferenciação, como atributo da construção identitária, é exaustivamente recorrente nas $M s$. O trecho abaixo ilustra a preocupação constante que o autor tem de diferenciar-se dos demais, sobretudo nos episódios relacionados à malandragem. Em um primeiro momento, para ele, o prestígio concedido ao malandro é condição indispensável à formação da identidade criminosa, pois quanto mais malandro, mais esperto, mais criminoso e, conseqüentemente, mais diferente dos iguais:

Ficaram admirando a minha roupa e abriram um sorriso enorme quando abri a bolsa e lhes mostrei o montão de dinheiro que possuía. Contei a façanha do roubo da loja, aumentando, é claro. Para eles, eu já era um malandro (esse era um título que eu queria muito), sujeito esperto a ser respeitado. Adorei o jeito reverente como me trataram. Gostei mesmo daquilo, deu-me enorme prazer! [...] Queria me mostrar mais malandro ainda, aproveitando a oportunidade para formar a minha nova identidade de vez. (O grifo é nosso) (MS, 2001, p. 49) ${ }^{2}$

Só que eu não conseguia ser apenas mais um. Precisava ser o centro, aquele que resolvia tudo. (MS, 2001, p.233)

No entanto, após um período de nove meses de confinamento na cela-forte ${ }^{3}$ da Penitenciária Estadual do Estado de São Paulo (depois de ter sido condenado a mais de cem anos de prisão por treze assaltos, um homicídio e um latrocínio), Luiz Alberto Mendes entra

\footnotetext{
${ }^{2}$ A partir de agora, no decorrer deste trabalho, a indicação da obra Memórias de um sobrevivente, de Luiz Alberto Mendes, será assinalada apenas com o número da página entre parênteses.

${ }^{3}$ Cela-forte era o nome dado ao local em que o preso ficava completamente isolado dos demais criminosos por um período mínimo de seis meses. Essas celas eram revestidas com azulejo nas paredes e com cacos de cerâmica no piso, repleto de pequenas poças de água. Além disso, das paredes da cela escorriam filetes de água. Eram, portanto, ambientes extremamente frios. $\mathrm{Na}$ época em que Luiz Alberto Mendes ficou, por noves meses, confinado nesse espaço, todos os presos submetidos ao regime da cela-forte deveriam permanecer nus (somente nos primeiros dez dias), estando sujeitos a doenças respiratórias, a maior causa mortis dos presidiários condenados a tal castigo.
} 
em contato com a literatura. Essa imersão no universo literário foi uma das principais razões que provocou uma mudança de paradigma na vida do presidiário, ou seja, ele trocou o crime pela literatura. Esta foi a grande responsável pelo seu processo de emancipação e, conseqüentemente, pela formação da sua nova identidade que, mais uma vez, deu-se pelo ato da diferenciação, pois

a partir dos romances, comecei a me interessar por livros mais profundos. As relações criminosas já não me satisfaziam mais. Pouco tinham a me acrescentar. [...] $\mathrm{O}$ submundo do crime começou a me parecer estreito, limitado, e eu já não cabia mais só ali. Voava alto, conhecera novos costumes, novos países, novas relações com a vida. (O grifo é nosso) (p.445)

A constituição da nova identidade de Luiz Alberto Mendes é profundamente marcada pela alteridade: "a identidade que nega o outro" (BERND, 2003, p.17) ou, ao contrário do que afirma Homi K. Bhabha, "a identidade [...] está inscrita no signo da semelhança” (1998, p. 83), uma vez que, ao entrar em contato com os livros e se tornar um leitor contumaz, a constituição da nova identidade do autor das $M s$ se processa no âmbito da diferença. $\mathrm{O}$ escritor aprisionado, portanto, se distancia dos demais detentos, negando os valores tão caros ao submundo do crime. A diferenciação, com a negação do outro, portanto, nas $M s$ é claramente percebida na contundente afirmação do autor de que, ao se questionar sobre os valores da vida bandida, promove uma virada total na sua existência e tenta jogar todo seu passado no lixo. De repente,

de um radicalismo pessimista, negativista, individualista e primitivamente violento, quis passar para um outro extremo, sem percorrer o caminho que leva de um extremo a outro. [...] Investi tudo num otimismo puro, numa mudança radical de mim mesmo. De bandido-homicidalatrocida, quis ser cidadão honesto e até meio santo. Larguei a maconha, cigarro, malandragem, contatos no meio criminal, até os amigos envolvidos no submundo aos poucos fui abandonando. Não havia mais afinidades. Dei uma virada total em minha existência. (p.460)

Ainda que o autor queira apagar seu passado criminoso, isso é praticamente impossível na medida em que ele depende das suas experiências pretéritas para a reconstituição da sua história. O contato com a linguagem e com a literatura, portanto, aguça a capacidade de reflexão de Luiz Alberto Mendes, promovendo a sua individualização. Por isso, ele afirma que trocou a faca pelo livro e que não queria mais ser bandido. A literatura para o autor das $M s$ representa a tábua de salvação para alguém que não pôde (re)agir contra o abuso de autoridade e contra as inúmeras formas de tortura a que foi submetido. Nas $M s$, para o narrador-personagem-autor escrever se apresenta como uma forma de (re)construir a identidade, de compreender-se e, sobretudo, de manter-se vivo. 
Embora sejam o mesmo ser, unidos, aliás, pelo uso do pronome de primeira pessoa, autor e personagem separam-se assinalando uma distância espacio-temporal de voz e de ponto de vista. Afinal, eles não podem ocupar o mesmo lugar no espaço, tampouco no tempo. Além disso, o leitor não pode esquecer-se de que aí se trata de um testemunho. Testemunho que, no caso, se difere do documento, porque é construído na perspectiva do sujeito-autor. Em Luiz Alberto Mendes, a literatura é testemunhal. ${ }^{4}$ Não a literatura nem o testemunho, mas o testemunho feito literatura.

Problematizando a ficção e a ficcionalidade, as $M s$ devem ser lidas como uma obra que merece o nome de literatura porque é o testemunho sobre a realidade histórica do sistema carcerário paulista-brasileiro-universal. Não abordaremos, nesse momento, a questão relacionada à ficção nas $M s$, pois esse aspecto será o objeto de nossa reflexão no quarto capítulo deste trabalho.

\section{As memórias de Proust ecoam nas Memórias de um sobrevivente}

Os estudos mais recentes acerca da memória têm remetido aos trabalhos dos estudiosos do final do século passado considerados fundadores, como os de Bergson, na área da filosofia; os de Freud, na da psicanálise; os de Ebbinghaus, na da psicologia; os de Proust, na da literatura; a partir dos quais se originaram inúmeras investigações, em diversas áreas do conhecimento, no início desse século.

Com relação a PROUST (2002a), os principais temas de Em busca do tempo perdido são o tempo e a memória. Sabe-se que Proust era obcecado pelas questões relativas ao tempo. Preocupava-o, e muito, o passar dos anos que leva tudo de arrasto, modificando, transformando, vencendo e extinguindo todos os sentimentos, paixões, amores, idéias, opiniões e até os corpos. Para esse autor, com o passar do tempo, o esquecimento e a indiferença sobem das profundezas do indivíduo para destruir tudo aquilo que o ser humano julgara eterno e intransferível. Nem mesmo aquele núcleo invariável do espírito, que a filosofia clássica acreditava formar a nossa personalidade, resiste à famigerada ação do tempo. Submerso no tempo, o homem se desagrega por dentro e nada mais subsiste, no velho, daquele jovem que um dia amou, fez uma revolução, ocupou altos cargos na esfera pública ou

\footnotetext{
${ }^{4}$ Fizemos essa afirmação com base na leitura de duas outras obras publicadas por Luiz Alberto Mendes, cujo caráter é testemunhal. Além de Memórias de um sobrevivente, esse autor publicou Tesão e prazer: memórias eróticas de um prisioneiro (MENDES, Luiz Alberto. Tesão e prazer: memórias eróticas de um prisioneiro. São Paulo: Geração Editorial, 2004) e Às cegas (MENDES, Luiz Alberto. Às cegas. São Paulo: Companhia das Letras, 2005).
} 
na iniciativa privada. E é em função do transcurso do tempo que as personagens proustianas apresentam aspectos diversos no decorrer da narrativa, mudando de idéias, de sentimentos, de gostos, como também se alteram suas características físicas, envelhecem. Ou, ainda, desenvolvem nova personalidade, mais criativa, mais madura. Por exemplo, o pintor que no grupo dos Verdurin era denominado, por zombaria, "Sr. Biche”, em No caminho de Swann, revela-se mais tarde, já maduro, como o famoso pintor Elstir, de À sombra das moças em flor. Mas o tempo prossegue em sua tarefa destruidora; e como recuperá-lo?

É justamente nesse momento que intervém a memória, outro tema capital da obra de PROUST (2002a). Não a memória comum (voluntária), produto da nossa inteligência, que a um mínimo esforço nos restitui os fatos pretéritos. Esta memória, que depende da nossa vontade, é como um simples arquivo: fornece apenas dados, fatos, datas, números e nomes. Mas não as sensações que experimentamos outrora e que não habitam a nossa consciência. Tais sensações jazem mais fundo e só são despertadas pelo que PROUST (2002a) denominou de memória involuntária, ou seja, aquela que não depende do nosso esforço consciente de recordar, que está adormecida em nós e que um fato qualquer pode fazer subir à consciência.

Sob esse aspecto, significativa é a lembrança, do narrador já adulto, da cidadezinha de Combray, de No caminho de Swann, onde passava as férias quando criança. Saboreando um biscoito molhado no chá, sente uma alegria inexplicável e, de súbito, recorda não só momentos similares da infância remota, como toda a Combray daquele tempo e todo o período de seu passado que o gosto do biscoito (chamado madeleine) fizera aflorar à sua consciência:

Fazia já muitos anos que, de Combray, tudo que não fosse o teatro e o drama do meu deitar não existia mais para mim, quando num dia de inverno, chegando eu em casa, minha mãe, vendo-me com frio, propôs que tomasse, contra meus hábitos, um pouco de chá. A princípio recusei e, nem sei bem por que, acabei aceitando. Ela então mandou buscar um desses biscoitos curtos e rechonchudos chamados madeleines [...], levei à boca uma colherada de chá onde deixava amolecer um pedaço da madeleine. Mas no mesmo instante em que esse gole, misturado com os farelos do biscoito, tocou meu paladar, estremeci, atento ao que se passava de extraordinário em mim. Invadira-me um prazer delicioso, isolado, sem a noção de sua causa. [...] De onde poderia ter vindo essa alegria poderosa? Sentia que estava ligada ao gosto do chá e do biscoito, mas ultrapassava-o infinitivamente, [...]. De onde vinha? Que significaria? [...]

E de súbito a lembrança me apareceu. Aquele gosto era o do pedacinho de madeleine que minha tia Léonie me dava aos domingos pela manhã em Combray. [...]

E logo reconheci o gosto de pedaço de madeleine mergulhado no chá que me dava minha tia (embora não soubesse ainda e devesse deixar para bem mais tarde a descoberta de por que essa lembrança me fazia tão feliz), logo a velha casa cinzenta que dava para a rua, [...], e a boa gente da aldeia e suas pequenas residências, e a igreja, e toda Combray e suas redondezas, tudo isso que toma forma e solidez, saiu, cidade e jardins, de minha xícara de chá. (Destaques do autor) (PROUST, 2002b, p. 51-53) 
No instante em que o narrador bebe o chá, acompanhado do biscoito madeleine, dá-se o reencontro do tempo e o passado se recupera. Como esse, muitos outros episódios, disseminados por toda a obra, atestam a importância do processo da memória involuntária para a recuperação do tempo perdido. Tempo que não existe mais entre e em nós, mas que continua a viver oculto num sabor, num aroma, numa flor, numa árvore, num calçamento irregular ou nas torres de uma igreja, entre outros. A repetição de tais episódios, dentro do conjunto da obra de Proust, longe de indicar monotonia ou pobreza criadora, é fundamental para estabelecer e cimentar as relações existentes entre as sensações e as lembranças. Esses momentos de reencontro do tempo nos dão a impressão da conquista da eternidade. Desse modo, o tema central de Em busca do tempo perdido não é propriamente o retrato da sociedade francesa do final do século XIX, nem a análise mais acurada do amor e dos sentimentos a ele relacionados, mas sim a luta do homem contra o tempo. E esse embate contra o tempo conta com o auxílio da memória como uma possibilidade de se encontrar na vida real um ponto fixo de referência ao qual o "eu" possa se prender.

Nas $M s$, as experiências vitais do escritor ao longo do tempo compõem o eixo sobre o qual o tecido narrativo se desenvolve, originando um tipo de escritura que pretende ser o lugar de excelência da reflexão do vivido por suscitar um aprofundamento consciente da reflexão acerca dessa experiência. Afirmamos que essa minúcia procede do fato de o escritor memorialista ter como particularidade, na recordação da experiência passada, o conhecimento da história que conta, partindo, portanto, do problema já resolvido.

A memória voluntária, de que nos fala PROUST 2002a é constantemente acionada por Luiz Alberto Mendes, narrador memorialista. Ao rememorar lugares, datas e nomes; enfim, alguns eventos significativos de sua vida - como a dura infância, marcada pela violenta presença do pai, e o presente da escritura das memórias, quando o escritor ainda cumpre o regime de prisão semi-aberta, por exemplo - é essa memória (voluntária) que emerge e revela as significativas cicatrizes, tão profundas quanto os horrores pelos quais o escritor passou no cárcere. A lembrança de tais fatos, no início e no final da narrativa, sugere que as chagas do escritor ainda estão abertas no momento em que ele narra o tempo vivido:

Meu pai, seu Luiz, dizia que eu era débil mental. Disso lembro bem. Diziam que me colocavam sentado em qualquer cadeira e ali eu permanecia durante todo o tempo. Quieto. Sem sair nem reclamar.

Depois, fui para a escola. Dizem que de santo virei diabo. Lembro da primeira professora, de régua em punho, exigindo disciplina. E não obtinha, pelo menos de mim. Enfiava a régua sem dó, ao menor descuido. Odiei a escola, odiei os professores. [...]

Meu pai, desde que me lembro, já bebia. Passava dias fora de casa, sem dar notícias. Quando voltava, dizia que fora preso em brigas pelos bares onde enchia a cara. Chegava xingando, brigando e falando alto. Fedia a cachaça e perfume barato. [...] 
Por qualquer motivo, mandava que eu fosse buscar o cinturão de couro no armário e dizia, sadicamente, que iríamos ter uma conversa. Era uma tortura, era mesmo! Pegava pelo braço e batia, batia, batia... até ficar sem fôlego. [...] Então me largava num canto, escondido do mundo; inteiramente só, chorando... Todo cortado por vergões roxos, querendo morrer para que ele sentisse culpa de minha morte. (p.13-14)

Lembro que muitos anos foram assim. Houve intervalos, o homem parava de beber por uns tempos e a vida ficava melhor. [...] Lembro das poucas vezes que ele conversou comigo. Tão poucas que não consigo lembrar um só tema de conversa, a não ser repressões. (p.21)

Ainda sou aquele, mas sou também outros. Sim, embora não acredite muito em mudanças do que somos, julgo mais correto pensar em aperfeiçoamento do que somos através do processo sedimentar. Quer dizer: sempre mudamos, mas funcionamos dentro de um eixo, o núcleo do que somos. [...]

Claro que há mazelas, hábitos e nervos em frangalhos, ninguém vive o que vivi impunemente. Há que pagar o preço, e confesso que é muito, mas muito mesmo, alto. (p.471477)

Por se tratar de experiências cruciais do autor, no tempo vivido, a memória voluntária (constantemente acionada por Luiz Alberto Mendes) se processa num constante ato de recordação, que se realiza num movimento retrospectivo, em direção ao passado, ao que já se perdeu no tempo narrado. Embora as sensações que experimentou outrora não habitem a sua consciência, permanecendo, portanto, armazenadas em suas camadas mais profundas, a memória involuntária, menos evidente nas $M s$, ao longo da narrativa pode ser identificada em dadas situações, tais como nos momentos em que o narrador se trai e revela ao leitor que, "aos dez anos já era um ladrãozinho bastante bem-sucedido (sic) e oportunista" (p.39), ou, por exemplo, no episódio em que o escritor rememora um espancamento que sofreu, ao ser surpreendido numa tentativa de fuga, quando tinha doze anos, na sua primeira passagem pelo juizado de menores. Esse ato de violência sofrido fez com que experiências pretéritas vivenciadas no convívio com o pai opressor viessem à tona, involuntariamente, no instante em que o escritor relembra o brutal acontecimento:

Apanhei daquele jeito como exemplo para que ninguém mais tentasse fugir. Eu sabia, sentira na pele, bateram com ódio, eram como meu pai, havia prazer neles, e eu lembrava que os funcionários riam, expressando claro prazer, em assistir ao espancamento. ( $\mathrm{O}$ grifo é nosso) (p.36)

Outro exemplo significativo da presença da memória involuntária nas $M s$ ocorre quando o escritor, após cometer um latrocínio, é capturado e levado à delegacia de polícia. $\mathrm{Na}$ sala de tortura dessa instituição, depois de passar por vários métodos de tortura, Luiz Alberto Mendes é conduzido a uma nova sessão de espancamentos. Nesse momento, a incisiva investida dos policiais contra si aciona, de modo involuntário, a lembrança do martírio sofrido na época em que era torturado pelo pai:

Após algumas pauladas e ameaças, deram-me uma sacola para carregar, e fui levado a uma salinha no mesmo corredor. Lá havia dois cavaletes e um cano de ferro. 
Quando tiraram o conteúdo da sacola é que percebi que carregava os instrumentos de tortura. Ali estavam as ataduras, as cordas de náilon, os fios, os cacetes (sic) e a máquina de choques. Recordou-me meu pai mandando que eu buscasse a cinta para ele me bater. (O grifo é nosso) (p.385)

\title{
3 A retenção da memória
}

A tentativa de reter a memória convida-nos a refletir sobre o seu processo evolutivo. E, nessa reflexão, é imprescindível que observemos a transição da oralidade à escrita e, conseqüentemente, o quanto elas se aproximam da memória, uma vez que, para LE GOFF,

\begin{abstract}
a utilização de uma linguagem falada, depois escrita, é de fato uma extensão fundamental das possibilidades de armazenamento da nossa memória que, graças a isso, pode sair dos limites físicos do nosso corpo para estar interposta, quer nos outros, quer nas bibliotecas. Isso significa que, antes de ser falada ou escrita, existe certa linguagem sob a forma de armazenamento de informações na nossa memória. (2003, p. 421)
\end{abstract}

A evolução da memória está profundamente relacionada com a implicação social na qual está inserida. A progressão do seu desenvolvimento, nas sociedades desprovidas de escrita, se deu, num primeiro momento, graças à prática da transmissão oral, um importante meio de resguardar o passado. Seguramente a transição da língua falada para a escrita foi um fator capital no processo de armazenamento da memória. Nessa transição, entretanto, devemos considerar o desempenho do narrador que constrói as memórias, ou seja, o sujeito que evoca os fatos pretéritos do seu próprio interior, cujas narrativas engendradas constituem espaços utópicos, ou seja, espaços em que o narrador "retorna" aos lugares outrora freqüentados, e espaços em que ele constrói os lugares em que nunca esteve. O fato de ter estado lá, juntamente com o de ter vivido em outras épocas, marca o domínio do narrador; na narrativa, o indivíduo delimita um espaço local e temporal habitável para si e para sua comunidade.

Prosseguindo em direção ao propósito deste estudo, é fundamental observarmos que o texto de Luiz Alberto Mendes tem como objeto de representação o próprio “eu”. Desse modo, os olhos incansáveis de Luiz Alberto Mendes criança-adolescente, transmutado em adulto, recriam com a palavra o mundo definitivamente ausente. $\mathrm{O}$ que parece frágil, inefável no confronto com o tempo, adquire forma na combinação das palavras e concretiza-se com o "subjetivismo unipessoal" (AUERBACH, 1971, p.459) de um "eu" narrativo que não se limita a observar apenas o exterior, mas que também se emaranha nas ações narradas através das próprias avaliações. Com relação ao subjetivismo unipessoal, AUERBACH (1971) o define como sendo aquele que só permite que fale um único ser cuja visão de realidade é a 
única válida. $\mathrm{O}$ resultado desse processo seria a representação da consciência unipessoal e subjetiva.

A consciência rememorante, também descrita por AUERBACH (1971), constitui a condição básica para a reconstrução do objeto ausente. No entanto, sem desprezar que na relação com a cultura e com a sociedade se delineia a identidade individual, ou, como quer HALL (2003), na relação com a cultura e com a nação, se delineia a identidade coletiva. Dito de outra forma, a definição da origem do indivíduo permite-lhe criar uma relação entre seu passado e o cosmos e, a partir daí, é possível determinar sua identidade, sua (in)dependência. O homem, quando se descobre em sua individualidade - além de criar meios de se autorealizar -, permite a si próprio assumir-se na sua totalidade ou na sua parcialidade, uma vez que, na modernidade tardia, os conceitos de sujeito e de identidade têm sido estudados sob a égide do fragmento.

\section{0 narrador de memórias}

A etimologia do vocábulo memória está relacionada tanto aos fatos da recordação, das lembranças, das reminiscências, como aos atos de narrar, referir, relatar. A memória é a faculdade de conservar e reproduzir as idéias, imagens ou conhecimentos anteriormente adquiridos; é a lembrança de qualquer coisa ou de alguém. Ela não é apenas a recordação, mas uma propriedade psíquica; enfim, é a narrativa do que é memorado.

O substantivo memória, pelo que demarca seu limite, alude a algo pessoal, individual, exclusivo. Entretanto, na medida em que nos é permitido raciocinar sobre as teorias de Michel Foucault (1992b) e de Roland Barthes(1988), no que diz respeito aos processos da escritura, no âmbito literário, é possível percebermos outros níveis na relação sujeito-escrita.

Podemos perceber, por exemplo, que a inexistência do autor deixa como herança unicamente a escritura e somente a partir dela é possível descobrir o texto. Há um ponto fundamental que devemos observar nessa escritura que se baseia numa relação inseparável com a morte. Nela há a possibilidade de admitir a finitude humana. Ela tanto pode adiar a morte tal qual se vê no exemplo de Sherazade, quanto pode perpetuar, imortalizar um herói na epopéia grega. Segundo FOUCAULT,

a narrativa ou a epopéia dos Gregos destinava-se a perpetuar a imortalidade do herói, e se o herói aceitava morrer jovem, era para que a sua vida, assim consagrada e glorificada pela morte, passasse à imortalidade; a narrativa salvava esta morte aceite. De modo distinto, a narrativa árabe - estou a pensar nas Mil e uma noites - tinha também como motivação, como tema pretexto, adiar a morte: contavam-se histórias até de madrugada para afastar a morte, para 
evitar o momento em que o narrador se calaria. A narrativa de Xerazade (sic) é o denodado reverter do assassínio, é o esforço de todas as noites para manter a morte fora do círculo da existência. (1992b, p. 35-6)

Esse espaço de tensão entre a vida e a morte, de modo análogo, também está presente na escritura das memórias. Podemos distingui-lo sob dois aspectos. Primeiramente, um que se centra na proximidade da morte, quando a velhice outorga ao sujeito autoridade para narrar experiências. Posteriormente, outro que está centrado no nervo da escritura que é capaz de propiciar, segundo FOUCAULT,

o apagamento dos caracteres individuais do sujeito que escreve; por intermédio de todo o emaranhado que estabelece entre ele próprio e o que escreve, ele retira a todos a sua individualidade particular; a marca do escritor não é mais do que a singularidade de sua ausência [...]. (1992b, p. 36)

Roland Barthes (1988), ao analisar o processo da escritura de forma semelhante, afirma que a escrita é a destruição de toda voz, de toda origem. Desse modo, a escrita é caracterizada pela sua neutralidade em função de o sujeito perder toda a identidade no momento em que escreve. BARTHES considera apenas o aspecto performativo da escrita, ou seja, o ato pelo qual a enunciação é proferida, e, além disso, atribui à cultura contemporânea o fato de a literatura estar "tiranicamente" (1988, p.66) centralizada na figura do autor, ou seja, na sua personalidade provida de costumes, sentimentos excessivos e defeitos, por exemplo. A partir dessa perspectiva, a obra pode ser compreendida e interpretada pelo sujeito que a produziu, que a concebeu, o que equivaleria dizer que para cada ficção haveria uma "confidência" (ibidem).

Ao citar Mallarmé, Roland Barthes observa que

para ele, como para nós, é a linguagem que fala, não o autor; escrever é, através de uma impessoalidade prévia, [...] atingir esse ponto onde só a linguagem age, "performa", e não "eu": toda a poética de Mallarmé consiste em suprimir o autor em proveito da escritura [...].(Destaques do autor) (BARTHES, 1988, p.66)

Como pudemos observar, então, o texto é um construto constituído por um campo sem origem, cuja ausência de originalidade ocorre em virtude da multiplicidade de escrituras que se mesclam em decorrência das diversidades culturais. Por isso, Barthes afirma que a unidade do texto encontrará seu destino no leitor que organiza, num único campo, a variedade de traços do qual se constitui.

Ao aceitarmos o texto sob tal panorama, estaremos eliminando o seu caráter confidencial e, assim, passaremos a considerá-lo como uma faculdade de ultrapassar a si próprio naquilo que sua escrita pode, como quer FOUCAULT, ser "transgredida ou invertida, ou seja, a escrita desdobra-se como um jogo que vai infalivelmente para além das suas regras, 
desse modo as extravasando" (FOUCAULT, 1992, p.35). Assim, o sujeito não se firma definitivamente na linguagem e, em vista disso, produz-se um espaço no qual tal indivíduo desaparece.

Segundo BARTHES (1988) e FOUCAULT (1992a) esse jeito de conceber a escrita com o apagamento da voz do autor, com a busca da neutralidade e com a perda da identidade autoral no ato da escritura - é uma característica da pós-modernidade. Embora Luiz Alberto Mendes componha suas memórias sob a égide do pós-moderno, ${ }^{5}$ ele é convidado a refletir sobre o modo antigo de narrar, defendido por Walter Benjamin (1993) em que o narrador se destaca, tem voz própria, não é neutro e tem identidade. Sejam citações, contestações, diálogos, mesclas culturais, sejam paródias, o texto conta uma história, narra algo que já é próprio da memória, da reminiscência e, por isso, segundo BENJAMIN "contar histórias sempre foi a arte de contá-las de novo, e ela se perde quando as histórias não são mais conservadas" (1993, p.205). Neste caso, o ato de conservar a história significa imortalizar a memória através do recontar.

No caso das $M s$, a escritura que quer resistir ao tempo, que almeja ser conservada, é a da experiência vivida, quando adolescente e adulto, pelo narrador mais experiente, mais "maduro". Se a categorizarmos como memória individual, entretanto, estaremos, certamente, banalizando-a, pelo simples fato de que as relações entre os seres humanos são organizadas a partir de "pontos de referência" (HALBWACHS, 1990, p.10). A memória individual estrutura-se na medida em que está simultaneamente ligada a uma existência social, isto é, às relações entre o indivíduo e o grupo social no qual está inserido. O narrador das memórias de $M s$, ainda que esteja envolto pelas tramas do coletivo, atribui a si próprio o direito à experiência individual: o caráter intimista dos escritos está profundamente relacionado ao destino inexorável do autor, que busca, na linguagem, um meio de organizar o caos em que viveu e ainda vive no ato da escritura. Devido a isso, ele cria imagens e as ordena desde a infância até o presente da composição da narrativa.

Recuperando a afirmativa de Walter Benjamin (1993) no que se refere à arte de contar histórias, chegamos, por meio de seu estudo, aos motivos pelos quais esta forma artesanal de comunicação entre o meio artesão desaparece. Desse modo, a extinção de tal técnica narrativa

\footnotetext{
${ }^{5}$ A maneira pós-moderna da tessitura narrativa de Luiz Alberto Mendes está relacionada ao modo como esse escritor reavalia e dialoga com seu passado, tentando presentificá-lo. Além disso, ao lermos $M s$ não restam dúvidas de que estamos diante de um jeito pós-moderno de "fazer" literatura, pois, embora o escritor tenha dito numa entrevista que realizamos com ele que "tudo na sua obra é verdade e realidade", na sua narrativa tudo se mistura; tudo se torna significante no processo de construção e significação narrativa; e se percebe que há uma linha muito tênue entre o que é verdade e o que é mentira, entre o que é ficção e o que é realidade, entre os limites da História (história de vida) e os da Literatura.
} 
tem como causa a ascensão do romance. Com efeito, a transformação que se dá no ato de contar histórias ocorre no sentido ouvinte-leitor. Quem se reunia em frente à lareira da sala de estar para ouvir uma voz disposta a transformar em arte um acontecimento cotidiano, encontra-se, nesse momento, na solidão da leitura, na inter-relação livro-leitor.

O romance, então, por estar vinculado ao livro, não permite mais o diálogo imediato, somente possível na oralidade. O narrador, entretanto, resistiu ao tempo e às transformações, uma vez que, por meio da escrita, tem procurado estabelecer um diálogo cultural com o leitor. Ainda que a narrativa oral tenha cedido lugar à narrativa do romance, acreditamos ser importante observarmos os pontos contíguos entre elas. Notemos, por exemplo, a célebre parábola contada por Walter Benjamin (1993) em que um velho só revela o verdadeiro sentido do tesouro a seus filhos em seu leito de morte. Como já afirmamos anteriormente, a velhice respalda e concede autoridade para narrar experiências. Quando cita Georg Lukács, Walter Benjamin destaca que

somente o romance [...] separa o sentido da vida, e portanto, o essencial e o temporal; podemos quase dizer que toda ação inteira do romance não é senão a luta contra o poder do tempo [...]. Desse combate, [...] emergem experiências temporais autenticamente épicas: a esperança e a reminiscência [...]. Somente no romance [...] ocorre uma reminiscência criadora, que atinge seu objeto e o transforma [...]. O sujeito só pode ultrapassar o dualismo da interioridade e da exterioridade quando percebe a unidade de toda a sua vida [...] na corrente vital do seu passado, resumida na reminiscência [...]. (1993, p.212)

A narrativa memorialística de Luiz Alberto Mendes não se distancia de tal aspecto. $\mathrm{O}$ narrador adulto trabalha a reminiscência. Os fatos desobedecem aos seus limites quando lembrados, e, com a maturidade, o adulto resume o passado nas lembranças, transmitindo as experiências por meio dos seus escritos. Excedendo as fronteiras dos fatos, a vida nas $M s$ é relatada de forma seca, ríspida, o que estabelece o pacto entre o leitor (confidente) e o narrador (confessor) é o interesse em conservar aquilo que foi vivido, tanto quanto em garantir a possibilidade de sua reprodução.

As $M s$ se alicerçam sobre um tradicional recurso da narração literária. A analepse ${ }^{6}$ é esse meio, pois permite que o narrador recue no tempo pela evocação de momentos pretéritos. Uma retrospecção que, às vezes, inverte a ordem cronológica dos acontecimentos:

Como certa vez a vó me pegara comendo seu neto querido, achava que a atitude dela tinha a ver com isso. Mais uma culpa a se acumular a outras tantas. Soube aos dezoito anos que havia era preconceito contra mim, por eu ser bastardo. (p.25)

Aos dez anos já era um ladrãozinho bastante bem sucedido e oportunista. (p.30)

\footnotetext{
${ }^{6}$ Em O tempo na narrativa, Benedito Nunes explica as anacronias baseado nas denominações dadas por Gérard Genétte em Dicours du récit: essais de methode. As anacronias são recursos tradicionais da narração literária entre as quais a analepse está inserida. Tal recurso permite ao narrador recuar no tempo através da evocação de momentos anteriores. Dessa forma, a narrativa poderá desenvolver-se na ordem inversa à cronológica.
} 
Tal recurso, todavia, na continuidade do discurso segue sem interrupção, ainda que o narrador intercale as seqüências retrospectivas com o presente. O tempo da narrativa transita, desse modo, entre o passado e o presente da enunciação, mas centrando, neste último eixo temporal, a concentração dos acontecimentos vividos, a partir do qual os eventos se organizam:

$\mathrm{O}$ ato dos PMS era tão conscientemente criminoso, que procuravam bater apenas onde não ficassem marcas duradouras. As palmas das mãos e as plantas dos pés. Só quando a vítima não se submetia àquele tipo de tortura é que eles batiam às queimas. E tínhamos pavor às surras às queimas. Eram borrachadas para todos os lados.

Só hoje sei que é muito mais fácil suportar uma surra geral do que sofrer tortura. Dói mais fisicamente, mas é muito menos danoso no nível psicológico. (O grifo é nosso) (p.117-118)

A partir da leitura do fragmento acima, podemos constatar que o narrador das $M s$ reorganiza os acontecimentos e elabora o discurso segundo a sua perspectiva atual. Com a realidade colocada à distância é possível que o fluir da imaginação gere momentos significativos de reflexão. O senso crítico do narrador adulto, então, poderá criar uma nova verdade para representar o vivido no presente da narração. Assim, o narrador distanciado desse tempo e espaço anteriores reorganiza, durante a sua maturidade, as suas lembranças. Enquanto caminha em direção ao futuro, reorganiza, no presente, o passado centrado nos fatos da infância e da experiência no cárcere. Por isso, um universo simbólico se constrói no interior das reminiscências, em que o narrador se assemelha ao mnemon que, embora contemporâneo, ainda arroga para si a função de (re)lembrar, não um herói como na Grécia Antiga, mas, principalmente, a sociedade carcerária.

O mnemon contemporâneo reconstrói o que foi conservado na consciência através da linguagem e organiza a representação dos acontecimentos vividos. A narrativa memorialística permite, assim, que o narrador expresse a si mesmo. Esse recurso narrativo, por apresentar a interioridade do protagonista, cria certa impressão do real, pois aquilo que está escrito corresponde aos fatos vivenciados por ele, como personagem. Dessa forma, cada capítulo das Ms desenvolve e registra fatos que, de algum modo, resgatam momentos decisivos para a existência de Luiz Alberto Mendes. Enfim, reproduz um monólogo narrativo que recupera um tempo esgotado, mas, talvez, não superado.

Juntamente com a consciência desse narrador, o leitor frui. Enquanto receptor que é, o leitor está limitado a formar uma idéia a respeito dos outros seres que habitam o texto, a partir de um único ponto de vista, o do narrador-protagonista. Este, à medida que dá vida aos outros personagens, revela a si próprio. Além disso, esse agente da enunciação recupera a existência 
dos outros quando estes participam de eventos que foram relevantes para a reconstrução de sua própria vida.

O narrador-protagonista das $M s$, pela sua posição limitada, não é onisciente. As personagens são delineadas, ao longo da narrativa, não pelo que se passa em suas mentes, mas por suas ações e pelo julgamento de um narrador que as materializa pela atribuição de características físicas, psicológicas, sociais e morais. Portanto, nas memórias de Luiz Alberto Mendes, há um centro imóvel de percepção que mantém o narrador dentro dos limites daquilo que sabe a respeito de si mesmo, das demais personagens e dos acontecimentos nos quais esteve envolvido.

\section{Referências}

AGOStinHO, Santo. Confissões. Trad. BARROS, Frederico Ozanam Pessoa de. Rio de Janeiro: Tecnoprint, 1991.

AUERBACH, Erich. A Meia Marron. In: Mimesis. Trad. SPERBER, Suzi Frankl. São Paulo: Perspectiva, 1971, p. 459.

BARTHES, Roland. A morte do autor. In: O rumor da língua. Trad. LAREANJEIRA, Mário. São Paulo: Brasiliense, 1988, p. 66.

BENJAMIN, Walter. Magia e técnica, arte e política. Trad. ROUANET, Sérgio Paulo. 5.ed. São Paulo: Brasiliense, 1993.

O narrador: considerações sobre a obra de Nikolai Leskov. In: . Magia $e$ técnica, arte e política. Trad. ROUANET, Sérgio Paulo. 5.ed. São Paulo: Brasiliense, 1993. p.205.

BERGSON, Henri. A consciência da vida. In: Os pensadores. Trad. SILVA, Franklin Leopoldo e. São Paulo: Nova Cultural, 1989b, p. 191 (Conferências).

. Introdução à metafísica. In: Os pensadores. Trad. , Franklin Leopoldo e. São Paulo: Nova Cultural, 1989c, p. 114.

. Matéria e memória: ensaio sobre a relação do corpo com o espírito. Trad. SILVA, Paulo Neves da. São Paulo: Martins Fontes, 1990, p. 119.

O pensamento e o movente. In: Os pensadores. Trad. , Franklin Leopoldo e. São Paulo: Nova Cultural, 1989a, p. 233 (Introdução).

BERND, Zilá. Literatura e identidade nacional. 2.ed. Porto Alegre: Editora da UFRGS, 2003.

BHABHA. Homi K. O local da cultura. Trad. REIS, Myriam Ávila, Eliana Lourenço de Lima e GONÇALVES, Gláucia Renate. Belo Horizonte: Editora da UFMG, 1998. 
BLANCHOT, Maurice. O espaço literário. Trad. CABRAL, Álvaro. Rio de Janeiro: Rocco, 1987.

CANDIDO, Antonio. Ficção e confissão: ensaios sobre Graciliano Ramos. Rio de Janeiro: Editora 34, 1992, p.58.

COMMELIN, P. Mitologia grega e romana. Trad. LOPES, Thomaz. Rio de Janeiro: Tecnoprint, Ediouro, 1978.

FOUCAULT, Michel. A escrita de si. In: $O$ que é um autor? Trad. CASCAIS, Antônio F. e CORDEIRO, Edmundo. Portugal: Veja-Passagens, 1992a, p. 133.

O que é um autor? In: $O$ que é um autor? 3.ed. Trad. CASCAIS, Antônio F. e CORDEIRO, Edmundo.Portugal: Vega-Passagens, 1992b, p. 35-6.

HALBWACHS, Maurice. A memória coletiva. Trad. SCHAFFTER, Laurent Leon. 2.ed. São Paulo: Revista dos Tribunais LTDA, 1990.

HALL, Stuart. A identidade cultural na pós-modernidade. Trad. SILVA, Tomaz Tadeu da e LOURO, Guaracira Lopes. 8 ed. Rio de Janeiro: DP\&A, 2003.

HEGEL, George. Fenomenologia del espíritu. Cidade do México, Fondo de Cultura Econômica, 1973, p. 108. Tradução do autor deste trabalho.

LE GOFF, Jacques. História e memória. Trad. LEITÃO, Bernardo et al. 5. ed. Campinas: Editora da Unicamp, 2003.

NESTROVSKI, Arthur; SELIGMANN-SILVA, Márcio (Orgs.). Catástrofe e representação. São Paulo: Escuta, 2000.

NUNES, Benedito. O tempo na narrativa. São Paulo: Ática, 1988.

PROUST, Marcel. A sombra das moças em flor. In: Em busca do tempo perdido. Trad. PY, Fernando. Rio de Janeiro: Ediouro, 2002. vol. I.

. Em busca do tempo perdido. Trad. PY, Fernando. Rio de Janeiro: Ediouro, 2002a.

. No caminho de Swann. In: Em busca do tempo perdido. Trad. PY, Fernando. Rio de Janeiro: Ediouro, 2002b. vol. I. 